\title{
ANTIGEN-SPECIFIC THERAPY FOR AUTOIMMUNE DISEASE: PROSPECTS FOR THE PREVENTION OF INSULIN-DEPENDENT DIABETES
}

\author{
Leonard C. Harrison
}

The Walter and Eliza Hall Institute of Medical Research, Royal Melbourne Hospital, Parkville, Victoria, Australia

The specific elements in a $\mathrm{T}$ cell-dependent immune response to a protein are: the peptide antigen; the MHC molecule, which binds the peptide antigen; and the cognate receptor of the $\mathrm{T}$ cell, which recognizes the peptide-MHC complex. Accessory costimulator molecules are required for a normal immune response but do not account for its specificity and diversity. Therapy to modify immune responses in a specific manner should therefore logically be targeted to one or more of these specific elements. A range of strategies (Table 1) centered on antigen, MHC molecule, or $\mathrm{T}$ cell receptor (TCR) have been shown to prevent the induction or favorably modify the natural history of autoimmune disease in rodents. Strategies centered on autoantigens have a clear advantage in human autoimmune disease. Theoretically, autoantigen-based therapy is generic (i.e., applicable to all individuals [who exhibit immunity, presumed pathogenic, to the autoantigen]), whereas the utility of MHC molecules or TCRs at the population level is limited by their polymorphism.

\section{TWO SIDES TO AN}

\section{AUTOANTIGEN: PATHOGEN AND PANACEA}

In considering antigen-specific therapy, an apparent dilemma for human autoimmunologists is the finding of immunity to multiple autoantigens even in so-called organ-specific autoimmune diseases: for example, insulin-dependent diabetes mellitus (IDDM) (1). Also, many autoantigens have a ubiquitous tissue distribution, although their role as potential pathogens to initiate and/or drive tissue-specific disease can be rationalized on the basis of tissue-specific processing/presentation of antigenic peptides with expression of costimulator molecules. What needs to be established are criteria that define autoantigens as pathogenic. At a minimum, immune responses to autoantigens should be disease specific, antedate the onset of clinical features, and correlate with clinical and other laboratory indices of disease. By analogy with Koch's postulates for microorganisms in infectious diseases, we should seek direct evidence for the pathogenicity of autoantigens. Models of autoimmune disease can be induced experimentally in animals by immunization with antigen (for example, experimental autoimmune encephalomyelitis (EAE) with myelin basic protein, thyroiditis with thyroglobulin, myasthenia gravis with acetylcholine receptor, or arthritis with collagen), and in these models antigen-specific $T$ cells from affected animals can transfer disease to immunized animals (2). The nonobese diabetic (NOD) mouse is a natural model of spontaneous autoimmune diabetes in which immunity to insulin and glutamic acid decarboxylase (GAD) is associated with destruction of the insulin-producing $\beta$ cells in pancreatic islets (3). Antigens in these animal models, including insulin (4) and GAD (5-7) in the NOD mouse, have been used as therapeutic agents to induce immune tolerance and modify favorably the natural history of disease. This demonstrates that they elicit immunity that is not only a disease marker, but is also pathogenic. Demonstrating that an autoantigen is a therapeutic tolerogen in an animal model is an important criterion of pathogenicity that can now be applied to autoimmune disease in humans. 
TABLE 1. Strategies of specific immunotherapy for autoimmune disease

\begin{tabular}{|c|c|c|c|c|}
\hline Strategy & Target & Modality & $\begin{array}{c}\text { Efficacy in } \\
\text { Experimental } \\
\text { Animal Models }\end{array}$ & $\begin{array}{l}\text { Clinical Trials } \\
\text { in Humans }\end{array}$ \\
\hline \multirow[t]{9}{*}{$\begin{array}{l}\text { Antigen-induced } \\
\text { tolerance }\end{array}$} & $\begin{array}{l}\mathrm{T} \text { cells (effector } \\
\text { or regulatory) }\end{array}$ & $\begin{array}{l}\text { Protein antigen or peptide } \\
\text { epitope }\end{array}$ & & \\
\hline & & Via tolerising route & & \\
\hline & & Transmucosal & Yes & Yes \\
\hline & & Transdermal & Yes & No \\
\hline & & In modified form & & \\
\hline & & Soluble excess & Yes & No \\
\hline & & Soluble peptide-MHC & Yes & No \\
\hline & & $\begin{array}{l}\text { With blockade of } \\
\text { "second signal" }\end{array}$ & Yes & No \\
\hline & & "Altered peptide ligand" & Yes & No \\
\hline \multirow[t]{3}{*}{ MHC blockade } & $\begin{array}{l}\mathrm{T} \text { cells (effector } \\
\text { or regulatory) }\end{array}$ & Anti-MHC mAb & Yes & No \\
\hline & & Anti-MHC-peptide mAb & Yes & No \\
\hline & & MHC antagonist peptide & Yes & No \\
\hline TCR blockade & Effector $\mathrm{T}$ cells & Anti-V $\beta$ mAbs & Yes & No \\
\hline $\mathrm{T}$ cell vaccination & Effector T cells & $\begin{array}{l}\text { Autoreactive T cell, TCR, } \\
\text { or TCR peptide }\end{array}$ & Yes & Yes \\
\hline
\end{tabular}

MHC, major histocompatibility complex; mAb, monoclonal antibody; TCR, T cell receptor; $\mathrm{V} \beta$, variable region of TCR $\beta$-chain.

\section{ANTIGEN-SPECIFIC TOLERANCE}

Antigen-specific modification of immune responses was described before the modern era of immunology (8) and probably underlies primitive "desensitization" procedures like deliberate exposure to poison ivy by native Indians. Antigen-specific tolerance may operate directly on effector $\mathrm{T}$ cells or via regulatory $\mathrm{T}$ cells by several mechanisms that are not necessarily mutually exclusive (Table 2), depending on the mode of antigen administration and other factors such as antigen dose. In the mouse, parenteral, highdose soluble protein antigen has been shown to

TABLE 2. Mechanisms for antigen-induced tolerance of effector $T$ cells

Deletion

Anergy

Suppression by regulatory $\mathrm{T}$ cells

Competition by regulatory $\mathrm{T}$ cells

Immune deviation delete antigen-specific T cells by apoptosis (9) or to selectively suppress cellular immunity (delayed-type hypersensitivity [DTH]) dependent on interleukin 2 (IL-2) and interferon- $\gamma$ (IFN $\gamma$ ) secreting $\mathrm{T}$ helper $1\left(\mathrm{~T}_{\mathrm{H}} \mathrm{l}\right)$ cells $(10)$. T cell anergy can be produced in vitro with analogs of immunogenic peptides termed altered peptide ligands (11) or by blocking the interaction between nonpolymorphic, costimulator "second signal" molecules on $\mathrm{T}$ cells and antigen presenting cells (e.g., between CD28 and B7) that are necessary for normal $\mathrm{T}$ cell activation by peptide-MHC complexes (12). Soluble protein antigen delivered orally to the intestinal mucosa suppresses the DTH response to antigen ("oral tolerance"), an effect associated with the induction of "regulatory" $\mathrm{T}$ cells that have a $\mathrm{T}_{\mathrm{H}} 2$-like profile (13). These regulatory cells, while antigen specific, are postulated to have an antigen-nonspecific, bystander suppressor effect in the target DTH lesion, mediated by the secretion locally of IL-4 and/or transforming growth factor- $\beta$ (13). An alternate mechanism of action for regulatory or anergic $\mathrm{T}$ cells, and an explanation of bystander tolerance, is competition with effector $\mathrm{T}$ cells for 
antigen peptides presented on a common antigen presenting cell (14). Regulatory T cells that either secrete "protective" cytokines or "crowd out" effector cells at the level of antigen presentation may account for "suppressor" phenomena frequently described in the immunology literature. Finally, the route or form of antigen presentation may result in deviation of immunity away from a pathogenic response (i.e., away from a $\mathrm{T}_{\mathrm{H}} \mathrm{l}$ response in the case of a DTH lesion).

\section{SUPPRESSION OF IDDM BY ISLET ANTIGENS IN RODENT MODELS}

While autoimmunity does not prove that an autoantigen is pathogenic, this may be deduced if the autoantigen can be used to modify the natural history of the autoimmune disease. In both the NOD mouse (15) and the BB rat models of spontaneous IDDM (16), subcutaneous insulin delays or prevents the onset of diabetes. Parenteral insulin could alter the natural history of preclinical IDDM by a metabolic effect to decrease blood glucose and "rest" the $\beta$ cell. However, a tolerogenic effect is evidenced by the delay in onset of diabetes after immunization of NOD mice with the inactive $B$ chain of insulin (17) or the 9-23 peptide of the B chain (18). A pathogenic role for GAD-reactive T cells in IDDM is strongly supported by the finding that soluble GAD injected intrathymically (5), intravenously (6), or intraperitoneally (7) in young NOD mice delays the onset and/or decreases the incidence of diabetes. By an alternative strategy, insulin given either orally (4) or as an aerosol (19) also retards diabetes development in NOD mice. Both oral and aerosol insulin induce regulatory $\mathrm{T}$ cells in the spleen that block the transfer of diabetes to young, nondiabetic NOD mice by splenic T cells from older, diabetic mice. Neither form of insulin administration has an acute or chronic effect on blood glucose.

\section{PRECLINICAL DIAGNOSIS OF IDDM IN HUMANS}

IDDM is an ideal model for the preclinical diagnosis and prevention of human autoimmune disease. A prerequisite for prevention is reasonably accurate prediction. First-degree relatives of a person with IDDM can be identified as having a low, moderate, or high risk for clinical disease, according to age, $\beta$ cell function, and the presence of circulating antibodies and $\mathrm{T}$ cells to islet antigens. The major known autoantigens, as in the NOD mouse, are insulin and GAD (1). Circulating insulin autoantibodies (IAA) (20), insulin-reactive T cells (21), GAD antibodies (22), and GAD-reactive T cells (23) have been reported with varying frequencies in at-risk relatives. Antibodies to GAD contribute to islet cell antibodies (ICA), the classic marker of IDDM detected by reactivity with the cytoplasm of islet cells in frozen sections of human pancreas. Young ( $<20$ years) relatives with high-titer ICA have at least a $30 \%$ risk of developing clinical IDDM within 5 years; the addition of IAA increases the risk to at least $50 \%$; if $\beta$ cell insulin release is impaired, the risk exceeds $80 \%$ (24).

\section{STRATEGIES FOR PREVENTION OF CLINICAL IDDM BY ANTIGEN- SPECIFIC THERAPY IN HUMANS}

Insulin and GAD are strong candidate tolerogens for the prevention of human IDDM. However, caution should be exercised with GAD because, unlike insulin, it is not $\beta$ cell-specific and is found in high concentrations in the brain as well as in peripheral tissues other than islets. Without further animal studies and knowledge of the GAD epitopes that elicit $\mathrm{T}$ cell reactivity unique to human $\beta$ cells, it would seem unwise to manipulate immunity to this widely distributed key enzyme. For the present, insulin (or proinsulin) is the only islet antigen that, both on scientific and ethical grounds, justifies therapeutic application to humans at risk of IDDM.

Based on results in the rodent models $(15,16)$, a small pilot study (25) suggested that parenteral insulin might delay the onset of IDDM in humans. This form of intervention will now be tested in a large, randomized trial, the Diabetes Prevention Trial-Type 1 Diabetes (DPT1), sponsored by the National Institutes of Health in the United States. Currently, $\sim 60,000$ first-degree relatives are being screened for ICA to identify about 400 high-risk subjects with high-titer ICA and impaired $\beta$ cell function, who will be randomized to parenteral insulin or control groups.

Double-blind trials of oral bovine myelin in multiple sclerosis (26) and type II chicken collagen in rheumatoid arthritis (27) have recently been reported. Although promising, these trials did not unequivocally demonstrate the efficacy 
of antigen-specific oral tolerance in humans. This has, however, recently been established by Husby et al. (28) in a seminal study with the experimental antigen, keyhole limpet hemocyanin (KLH). KLH ingestion significantly reduced T cell proliferation and the skin DTH response, and increased the antibody response, to subsequent KLH immunization. This deviation of immunity from $\mathrm{T}$ cell to $\mathrm{B}$ cell responses was previously reported after feeding low doses of soluble protein antigens to mice (13). A trial of oral insulin in high-risk ICA-positive relatives is planned in the National Institutes of Health-sponsored intervention program.

Nasopharyngeal or respiratory delivery of soluble protein also induces tolerance at the $\mathrm{T}$ cell level. In fact, acetylated N-terminal peptides of myelin basic protein that induce EAE when given subcutaneously with adjuvant protect against disease induction if first given intranasally, but not if first given orally (29). Intranasal or aerosol inhalation might therefore be the preferred route for the induction of mucosal tolerance, at least for certain peptides. Clinical trials of intranasal or aerosol antigens have not been reported in humans, but Waldo et al. (30) recently showed that KLH given intranasally to adult volunteers resulted in $\mathrm{T}$ cell tolerance with deviation from $\mathrm{T}$ cell to $\mathrm{B}$ cell immunity.

Oral, aerosol or intranasal insulin should be acceptable and practical tolerogenic modes of delivering insulin. Certainly, they would seem preferable to parenteral insulin in young people at risk for IDDM, in whom an objective of intervention treatment is to abolish the need for daily injections! The impetus to embark on intervention trials is strong but the scientific rationale is still relatively weak and many questions pertinent to guiding intervention in humans remain unanswered. The study of Zhang et al. (4) is really the only published full description of the effect of mucosal (oral) insulin in delaying the onset of diabetes in an animal model, the NOD mouse. It can be argued that their results should be extended to gain detailed insight into the efficacy of different delivery modes, doses, and schedules, as a basis for optimizing insulin-specific immunotherapy in humans.

What is the optimum dose of insulin and frequency of administration? What factors affect the reproducibility of its effect? Is treatment effective if started after the onset of islet autoimmunity? This last question is a critical one, because human candidates for intervention therapy will, initially at least, be required to have immune markers denoting high risk for clinical disease. Might proinsulin be more effective than insulin? There is intriguing evidence $(31,32)$ that a peptide spanning the cleavage site between the B-chain (of insulin) and the connecting (C) peptide in proinsulin is immunogenic in IDDM. Is aerosol or intra-nasal insulin more effective than oral insulin? Intra-nasal insulin was first used in humans in 1923 (33) and evaluated subsequently in clinical trials as a possible hypoglycaemic (34). Compared with oral insulin, intranasal insulin might have the advantages of a lower dose requirement, more direct delivery to the mucosa, less degradation and variability of adsorption and therefore less interdose variance of delivery. What are the immunogenic and tolerogenic $\mathrm{T}$ cell epitopes within (pro)insulin? Are there reliable and reproducible surrogate markers (e.g., insulin-reactive $\mathrm{T}$ cells) with which to monitor whether immunotherapy is likely to have the expected long-term effect of reducing the incidence of clinical disease?

These are important practical questions, the answers to which would take some of the guesswork out of the design of human trials. Proposed large-scale trials of insulin-based immunotherapy in at-risk relatives could do well to proceed cautiously while addressing these questions, despite pressure for action from various interested parties. There is not only an ethical obligation to provide a reasonably sound scientific rationale, but the logistics and costs of intervention trials are daunting.

\section{ACKNOWLEDGMENTS}

I thank Drs. Margo Honeyman, Andrew Lew, and George Rudy for their comments and Mrs. Margaret Thompson for secretarial assistance.

\section{REFERENCES}

1. Harrison LC. (1992) Islet cell autoantigens in insulin-dependent diabetes: Pandora's box revisited. Immunol. Today 13: 348-352.

2. Paul WE. (1993) Fundamental Immunology. 3rd Ed. Raven Press, New York.

3. Kikutani H, Makino AS. (1992) The murine autoimmune diabetes model: NOD and related strains. Adv. Immunol. 51: 282-322.

4. Zhang ZH, Davidson L, Eisenbath G, Weiner HL. (1991) Suppression of diabetes in nonobese diabetic mice by oral administration of 
porcine insulin. Proc. Natl. Acad. Sci. U.S.A. 88: $10252-10256$.

5. Tisch R, Yang X-D, Singer SM, et al. (1993) Immune response to glutamic acid decarboxylase correlates with insulitis in non-obese diabetic mice. Nature 366: 72-75.

6. Kaufman DL, Clare-Salzler M, Tian J, et al. (1993) Spontaneous loss of T-cell tolerance to glutamic acid decarboxylase in murine insulin-dependent diabetes. Nature 366: 6972.

7. Petersen JS, Karlsen AE, Markholst H, et al. (1994) Neonatal tolerisation with glutamic acid decarboxylase but not with bovine serum albumin delays the onset of diabetes in NOD mice. Diabetes 44: 1478-1484.

8. Wells H. (1911) Studies on the chemistry of anaphylaxis. III. Experiments with isolated proteins, especially those of the hen's egg. $J$. Infect. 9: 147-151.

9. Critchfield JM, Lenardo MJ. (1995) Antigeninduced programmed $\mathrm{T}$ cell death as a new approach to immune therapy. Clin. Immunol. Immunopathol. 75: 13-19.

10. Burstein HJ, Shea CM, Abbas AK. (1992) Aqueous antigens induce in vivo tolerance selectively in IL-2- and IFN- $\gamma$-producing (Thl) cells. J. Immunol. 148: 3687-3691.

11. Evavold BD, Sloan-Lancaster J, Allen PM. (1993) Tickling the TCR: Selective T-cell functions stimulated by altered peptide ligands. Immunol. Today 14: 602-609.

12. Johnson JG, Jenkins MK. (1994) The role of anergy in peripheral $\mathrm{T}$ cell unresponsiveness. Life Sci. 55: 1767-1780.

13. Weiner HL, Friedman A, Miller A, et al. (1994) Oral tolerance: Immunologic mechanism and treatment of animal and human organ-specific autoimmune disease by oral administration of autoantigens. Annu. Rev. Immunol. 12: 809-837.

14. Lombardi G, Sidhu S, Batchelor R, Lechler R. (1994) Anergic T cells as suppressor cells in vitro. Science 264: 1587-1589.

15. Atkinson M, Maclaren N, Luchetta R. (1990) Insulitis and diabetes in NOD mice reduced by prophylactic insulin therapy. Diabetes 39: 933-937.

16. Gotfredsen CF, Buschard K, Frandsen EK. (1985) Reduction of diabetes incidence of BB Wistar rats by early prophylactic insulin treatment of diabetes-prone animals. Diabetologia 28: 933-935.

17. Muir A, Peck A, Clare-Salzler M, et al. (1995) Insulin immunization of nonobese diabetic mice induces a protective insulitis characterized by diminished intraislet interferon- $\gamma$ transcription. J. Clin. Invest. 95: 628634.

18. Wegmann DR, Gill RG, Norbury-Glaser M, Schloot N, Daniel D. (1994) Analysis of the spontaneous $\mathrm{T}$ cell response to insulin in NOD mice. J. Autoimmun. 7: 833-843.

19. Harrison LC, Dempsey-Collier M. (1994) Autoantigen-specific suppression of diabetes development in non-obese diabetic (NOD) mice. Proc. Aust. Diab. Soc. Abstr. 79, p. 73.

20. Palmer JP, Asplin CM, Clemons P, et al. (1983) Insulin antibodies in insulin-dependent diabetics before insulin treatment. Science 222: 1337-1339.

21. Harrison LC, Chu XS, DeAizpurua HJ, Graham M, Honeyman MC, Colman PG. (1992) Islet-reactive $\mathrm{T}$ cells are a marker of preclinical insulin-dependent diabetes. J. Clin. Invest. 89: 1161-1 165.

22. DeAizpurua HJ, Wilson $Y$, Harrison LC. (1992) Glutamic acid decarboxylase (GAD) autoantibodies in pre-clinical insulin-dependent diabetes. Proc. Natl. Acad. Sci. U.S.A. 89: 9841-9845.

23. Honeyman MC, Cram DS, Harrison LC. (1993) Glutamic acid decarboxylase 67-reactive T cells: A marker of insulin-dependent diabetes. J. Exp. Med. 177: 535-540.

24. Bingley PJ, Bonifacio E, Gale EAM. (1993) Can we really predict IDDMM? Diabetes 42: 213-220.

25. Keller RJ, Jackson RA, Eisenbarth GS. (1993) Insulin prophylaxis in individuals at high risk for the development of type 1 diabetes mellitus. Lancet 341: 927-928.

26. Weiner HL, Mackin GA, Matsui $M$, et al. (1993) Double-blind pilot trial of oral tolerization with myelin antigens in multiple sclerosis. Science 259: 1321-1324.

27. Trentham DA, Dynesius-Trentham RA, Orav EJ, et al. (1993) Effects of oral administration of type II collagen on rheumatoid arthritis. Science 261: 1727-1730.

28. Husby S, Mestecky J, Moldoveanu Z, et al. (1994) Oral tolerance in humans. J. Immunol. 152: 4663-4670.

29. Metzler B, Wraith DC. (1993) Inhibition of experimental autoimmune encephalomyelitis by inhalation but not oral administration of the encephalitogenic peptide: Influence of MHC binding affinity. Int. Immunol. 5: 11591165.

30. Waldo FB, Van Den Wallbake AWL, 
Mestecky J, Husby S. (1994) Suppression of the immune response by nasal immunization. Clin. Immunol. Immunopathol. 72: 3034.

31. Rudy G, Brusic V, Harrison LC, Lew AM. (in press) Sequence similarity between $\beta$-cell autoantigens. Immunol. Today.

32. Rudy G, Stone N, Harrison LC, et al. (1995) Similar peptides from two beta cell auto- antigens, proinsulin and glutamic acid decarboxylase, stimulate $\mathrm{T}$ cells of individuals at risk for insulin-dependent diabetes. Mol. Med. 1: 625-633.

33. Woodyatt RT. (1923) The clinical use of insulin. J. Metab. Res. 2: 793-801.

34. Gizurarson S, Bechgaard E. (1991) Intranasal administration of insulin to humans. Diab. Res. Clin. Prac. 12: 71-84. 